\title{
Sociālās vides determinanti un to ietekme uz dzimumnoziedznieku kriminoloǵisko raksturojumu
}

\author{
Mg. iur. Aldona Kipāne \\ Rìgas Stradiña universitātes doktorantūra, Latvija
}

\section{Kopsavilkums}

Raksta mērḳis ir sniegt atbildi uz to, kā sociālā vide ietekmē seksuālo noziedznieku personību. Izpētes gaitā vienkopus ir koncentrētas vairāku zinātnieku atziṇas un informācija par vides ietekmi uz dzimumnoziedznieka personības veidošanos un attīstību.

Atslēgvārdi: seksuālais noziedznieks, vides ietekme, kriminologiskais raksturojums.

Dažādi kriminoloǵiskie pētījumi un analīze ḷauj izteikt vairākus secinājumus par noziedzības faktoru kompleksu. Noziedzību noteicošo faktoru ir daudz, un tie l̦ti strauji mainās, - tikpat strauji, cik sabiedrība. Noziedzību, arī vardarbīgo, kā sociālu parādību pilnībā ietekmē šādi faktori:

1) sociāli ekonomiskie;

2) politiskie;

3) tiesiskie;

4) regionālie;

5) individuālie u. c.

Vardarbīgās noziedzības cēloṇus iedala iekšējos jeb individuālos un ārējos. "Iekšējie cēloṇi ir saistīti ar cilvēka kā personības veidošanos, audzināšanu, raksturu, attiecībām giimenē, ar bērnībā un jaunībā pārdzīvotām garīgām un fiziskām traumām. Šie apstākḷi nosaka cilvēka pasaules uzskatu, attieksmi pret apkārtējiem, vērtību sistēmu. Ārējie faktori ir saistīti ar cilvēka apkārtējo vidi un tās ietekmi." [2]

Raksta mērḳis ir analizēt sociālās vides ietekmes uz dzimumnoziedznieka personību kriminologisko aspektu. Šāds pētījums ir aktuāls un būtisks, jo parāda dažādu pētnieku darba rezultātus. 
Aldona Kipāne. Sociālās vides determinanti un to ietekmes uz dzimumnoziedznieku kriminologiskais raksturojums

Pētijjuma gaitā izmantotas šādas metodes: aprakstošā, juridiski logiskā un dokumentālā.

Seksuāla vardarbība ir jebkāda uzspiesta seksuāla aktivitāte, kurā upuris tiek iesaistīts bez piekrišanas. Seksuālā vardarbība visbiežāk ir saistīta ar spēka pielietošanu, fizisku piespiešanu, fizisku varmācību, iebiedēšanu un fiziskiem draudiem vai draudiem mutvārdos.

Vardarbība ir daudzškautņaina parādība, kas saistīta ar personas, vides un sociāli kulturālo faktoru mijiedarbību. Tã izpaužas četros līmeṇos (sk. 1. att.), kurus veido:

1) individuālais līmenis (indivīds);

2) gimenes konteksts (savstarpējās attiecības);

3) kopiena;

4) sabiedrïba $[12,13]$.

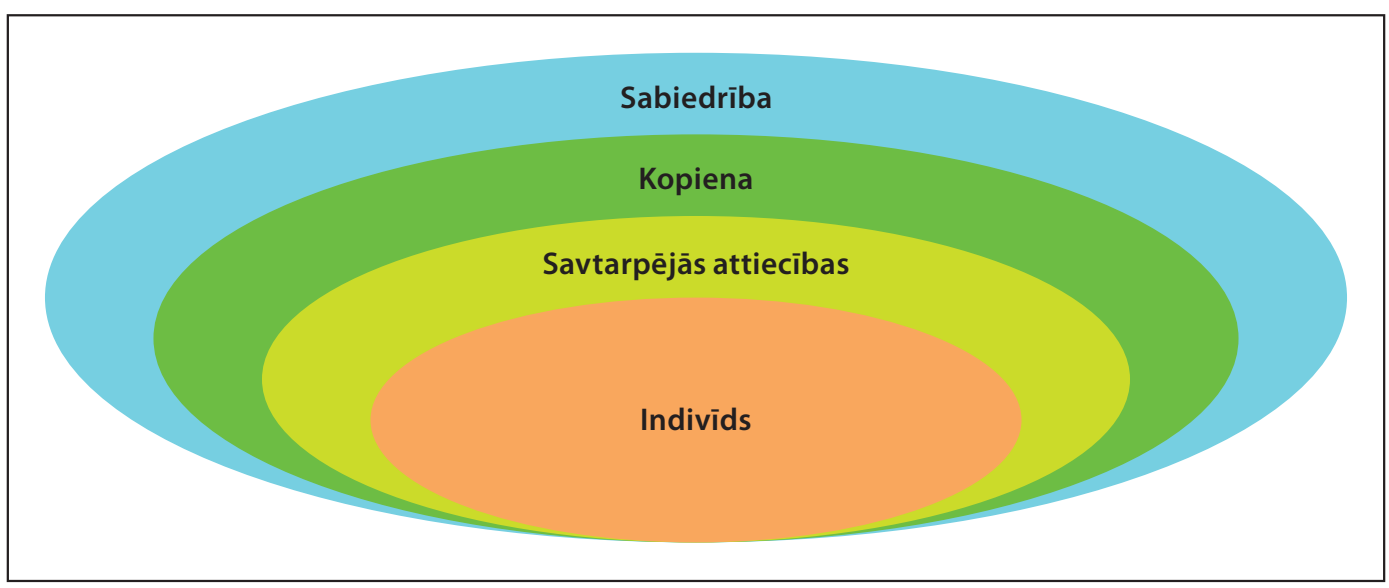

1. attēls. Vardarbïbas interpretācijas ekolog̣iskais modelis

Apkārtējās vides ietekmi uz personu skaidro vairākas teorijas, atklājot psihosociālos, biokīimiskos, genētiskos un fizioloğiskos iemeslus. Pēdējos gados attīstās jauna sociālā un biolog̣iskā pieeja, pētot vardarbỉbu. To sauc par evolucionāro psiholog̣iju. Norvēgijas speciālisti I. Mjusteruds un D. V. Polesdžinskis (Mysterud E Poleszynski) raksta, ka tradicionāli sabiedriski zinātniskais uzskats fokusējas uz vides psihosociāliem faktoriem. Pētnieki norāda uz jauniem apkārtējās vides faktoriem, kas var veicināt vardarbīgu uzvedību, piemēram, uz pārtikas uzturvērtības samazināšanos, kas tieši var novest pie hipoglikēmijas (pēkšña glikozes līmeṇa pazemināšanās asinīs), pārtikas alerğiju, jaunu kaitīgo vielu (smago metālu, sintētisko materiālu u. tml.) koncentrācijas palielināšanos atmosfērā $[12,29]$.

Amerikāṇu pētījumi parādīja, ka hipoglikēmija konstatēta $80-85 \%$ vardarbīgo noziedznieku. Jauni cilvēki, kuri izdarījuši vardarbīgus noziegumus, bieži cieš ne tikai no hipoglikēmijas, bet arī no pārtikas alerǵijas vai kādu produktu nepanesības. 
Aldona Kipāne. Sociālās vides determinanti un to ietekmes uz dzimumnoziedznieku kriminologiskais raksturojums

Smagie metāli (kadmijs, varš, svins, mangāns u. c.) saistāmi ar afektīvo agresiju. Amerikāṇu pētỉjumos ir ziṇas, ka $86 \%$ varmāku matos bija konstatēta smago metālu koncentrācija. Jāpiekrīt, ka šis būtībā ir jauns izpētes lauks vardarbīgo noziedzību ietekmējošo faktoru jomā.

D. Finkelhors (Finkelhor) savā četru priekšnoteikumu model̦a teorijā (Finkelhor's Four Preconditions Model) norādījis, ka seksuāā vardarbība pret bērnu, uzmākšanās bērniem (child molestation) ir komplicēts fenomens, un tā pamatā ir dažādi faktori. Tajos ietilpst psiholog̣iskās vajadzības un noziedznieka motīvi, situācijas un konteksta mainība, audzināšanas prakse, sociālā attieksme pret bērnu un seksu [11,20].

Jāpiemin, ka pētnieki, vērtējot dažādu pamata faktoru nozīmīgumu jaunu cilvēku seksuālajai agresijai, nonākuši pie secinājuma, ka nav viena faktora vai pieredzes, kas jauniešiem attīsta seksuāli agresīvu uzvedību. Vairāku faktoru sakopojums, piemēram, personīgā ḷaunprātīgās izmantošanas pieredze, piesaistes vai pieķeršanās problēmas, gimenes attīstība, vardarbības pieredze, uzvedības problēmas un nepietiekamas sociālās zināšanas un spējas, kuras saistìtas ar seksuālu virzību, - tas viss pamudina jaunus cilvēkus kḷūt par seksuāliem noziedzniekiem.

Dažos pētījumos pierādīts, ka seksuāli vardarbīgas uzvedības iemesli ir nelabvēlīga ǵimenes vide, kas tiek raksturota ar dažādām l̦aunprātīgas izmantošanas un nevērības formām. Audzināšanas un padomu trūkums noved pie problēmām sociālajā funkcionēšanā (neuzticēšanās, naidīgums un nedroša piesaiste, kas atkal ir iemesls sociālajam noraidījumam, vientulībai, negatīvām attiecībām ar sev lìdzīgajiem un delinkventai uzvedībai). Seksuāli deviantās uzvedības veida raksturojumu sk. 2. attēlā $[9,100]$.

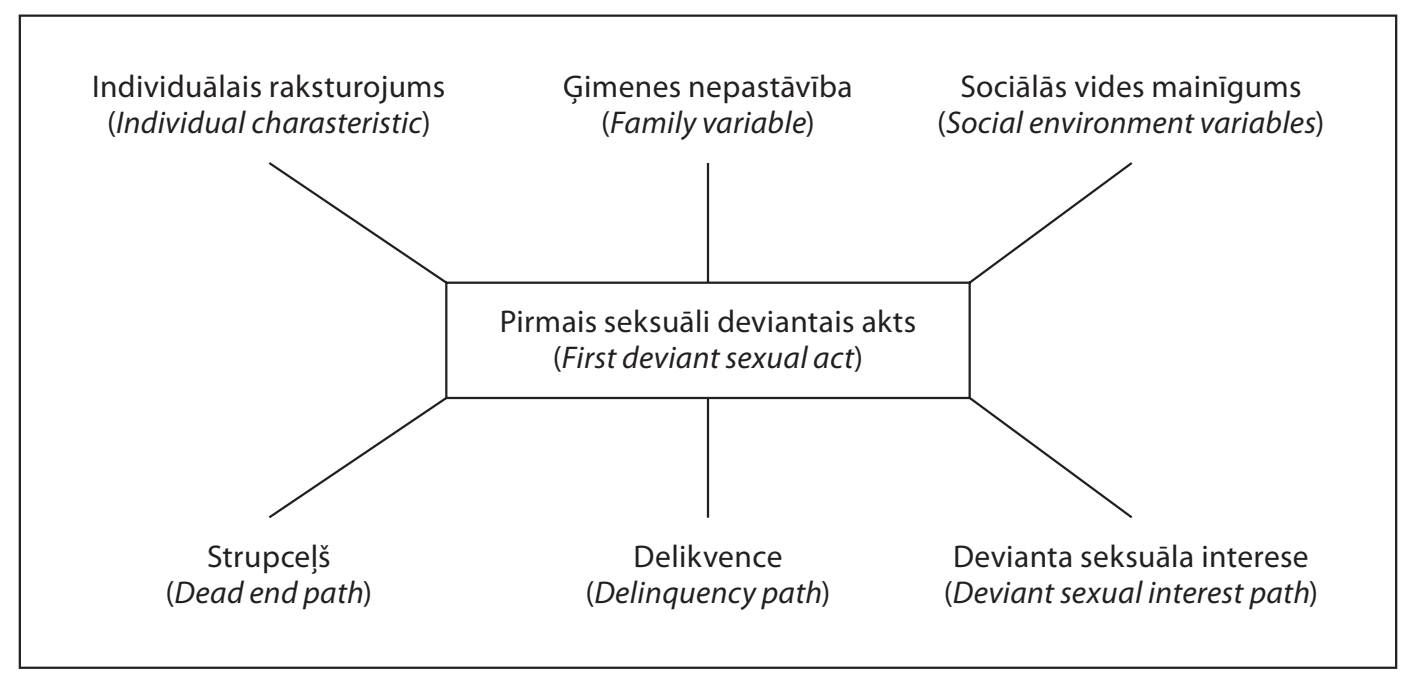

2. attēls. Seksuāli deviantās uzvedības ietekmes shēma (Becker E Kaplav. Mode of deviant sexual behaviour) 
Aldona Kipāne. Sociālās vides determinanti un to ietekmes uz dzimumnoziedznieku

kriminologiskais raksturojums

Multidisciplināri pētījumi liecina, ka noziedzīgas uzvedības aizsākums gandrīz vienmēr ir meklējams ğimenē, tajos apstākḷ̆os, kādos aug bērns. Vairākos pētījumos pierādīta saistība starp vecāku kriminālo pagātni un tās ietekmi uz bērnu. G̦imenēs, kur vecākiem ir krimināla pagātne, novērojama lielāka bērna kriminālās uzvedības varbūtība nekā g̣imenēs bez kriminālās pagātnes.

Nìderlandes pētnieki Van de Rakts, Nieuvberta un De Grāfs (Van de Rakt, Nieuwbeerta, De Graaf), izanalizējot 4271 notiesāta vīrieša pagātni un viṇu 6962 bērnus, un 717 netiesātu vīriešu un viṇu 1133 bērnus, konstatēja, ka bērni, kuru tēvu pagātnē ir pastāvīga un noturīga sodāmība, biežāk kḷūst par noziedzniekiem [16]. Austrālijas pētỉjumā apzināts, ka šādas tendences novērotas ap 76\% zēnu un 80\% meiteṇu [6].

Vērojama, piemēram, šāda daudzpusējā cēlonības saistība:

\section{vāja aprūpētāja piesaiste $\rightarrow$ sliktākas sekmes skolā $\rightarrow$ konflikti gimenē $\rightarrow$ atsvešināšanās no ğimenes $\rightarrow$ identificēšanās ar līdzigo $\rightarrow$ ar grupu saistìts noziedzìgs nodarijums [5, 17].}

Pamatoti tiek norādīts, ka "gimenē tiek īstenotas indivīda un sabiedrības pamatvērtības un apmierinātas galvenās vajadzības, tajā norit indivīda attīstība un personības veidošanās process. Personībai būtisks ne tikai ikdienas organizācijas elements, bet arī emocionālā piesaiste, kas rada drošības un piederības izjūtu" [1,26]. Sociālās vides ietekme var būt gan pozitīva, gan arī negatīva (izkroplota informācija, kaitīgi ieradumi). Bērni socializējas vērojot, atdarinot un vērtējot paraugus, līdzdarbojoties un mācoties. Personības socializāciju ietekmē vairāki sociālās vides faktori (sk. 1. tab.) $[4,21]$.

\section{1. tabula. Personības socializāciju ietekmējošie sociālās vides faktori}

\begin{tabular}{|l|ll|}
\hline G̦imene & $\Rightarrow$ & Zināšanas (informācija) \\
Tuvākie apkārtējie - draugi, vienaudži, kolēǵi utt. & Prasmes \\
Masu informācijas līdzekḷi & Attieksmes, uzvedība \\
lestādes, piemēram, skola, augstskola, darbavieta, interešu & leradumi, dzīvesveids, \\
grupas utt. & Sociālo lomu apguve \\
\hline
\end{tabular}

Jāpiebilst, ka, pamatojoties uz tiesu psihiatrijas materiāliem, Zviedrijā veiktā pētỉjumā konstatēta nevērība, launprātīga izmantošana un nošçiršana ğimenē, jauniešiem novērota hiperaktivitāte un koncentrēšanās grūtības. Vairākums jauniešu pārcietuši nevērību, atstumtību vai emocionālo vardarbību. Viena pētījuma rezultāti rādīja, ka 61\% jauno seksuālo noziedznieku piedzīvojuši aizskaršanu (t. s. bulingu), trešdalıa šīs grupas noziedznieku ir sodīti ar izolāciju no sabiedrības [7, 100]. Pētījumi pierādỉjuši, ka jauniešiem, kuriem ir siltas, sirsnīgas, tuvas attiecības ar vinu vecākiem, pastāv mazāks uzvedības problēmu risks; un otrādi, tiem jauniešiem, kuriem nav izveidojušās ciešas attiecības ar vecākiem, ir lielāka iespējamība, ka viṇiem būs uzvedības problēmas [3, 24]. Šo sakarību rāda Malamuta modelis: vīrieša īstenots piespiešanas modelis (Malamuth's model of the characteristcs of coercive men) (sk. 3. attēlu) [6, 83]. 
Aldona Kipāne. Sociālās vides determinanti un to ietekmes uz dzimumnoziedznieku kriminologiskais raksturojums

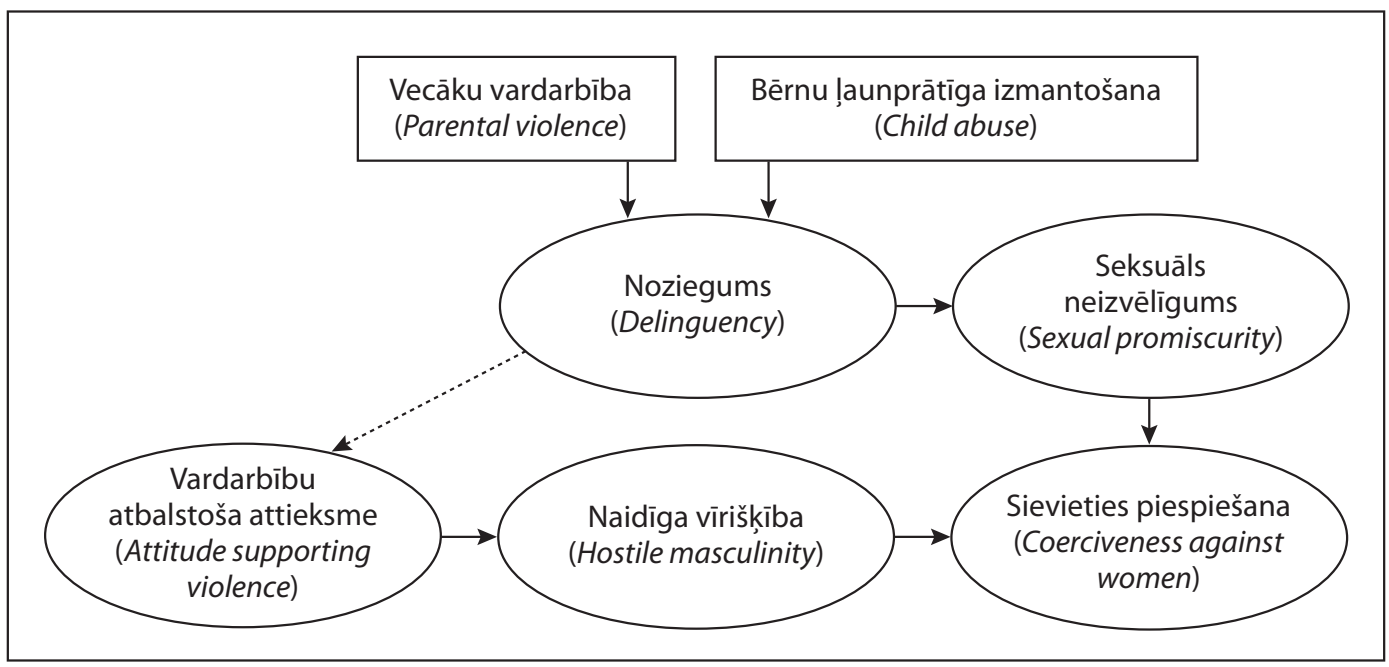

3. attēls. Malamuta modelis: vīrieša īstenota piespiešanas modeḷa raksturojums

G̦imenes lomas nozīme, īpaši attieksme pret nepilngadīgo, ir acīmredzama. Ja ğimenē bērni nejūtas saprasti, viṇi mēdz atteikties no savas vērtību izpratnes, lai izpelnìtos atzinību no vienaudžiem, bērni veic deviantas darbïbas. Nenoliedzami, paaugstinot gimenes lomu sabiedrībā, var sekmēt arī tās nozīmīgumu sabiedrībā un stimulēt tās patstāvību un noturību. Rīcības plānā nepilngadīgo aizsardzībai no noziedzīgiem nodarījumiem pret tikumību un dzimumneaizskaramību 2010.-2013. gadam [18] atzîts, ka liela nozìme ir gimenei, ka būtiskas ir gan attiecības starp vecākiem, gan vecāku attieksme pret bērnu. Taču veiksmīga socializācija iespējama tikai tad, ja gimenē ir pietiekamas zināšanas par to, kā šo procesu îstenot. Tāpēc liela nozīme ir sabiedrības izglìtošanai.

Norādot uz vardarbības gimenē plašāko problemātiku, jāakcentē ǵimenes nozīmīgums, jo tajā veidojas cilvēka personība. Latvijas tiesību zinātnieki neizdala atsevišḳu kriminologijas kategoriju "gimenes kriminolog̣ija" jeb "gimenes attiecību kriminolog̣ija", tomēr, pēc manām domām, šāda kategorija jāattīsta. Zināmā mērā gimene ir indivīda attiecību ar sabiedrību modelis, jo ğimene veic socializācijas funkciju, t. i., cilvēka piemērošanos dzīvei sabiedrībā.

Ministru kabineta 2011. gada 5. oktobra rīkojumā Nr. 504 "Par sabiedrības veselības pamatnostādnēm 2011.-2017. gadam” [17] atzìts, ka nozīmīgs ir ekonomiskais nodrošinājums, ka dzīve nabadzībā biežāk ir saistìta ar t. s. riska uzvedību - biežāku psihoaktīvo vielu (tabakas, alkohola) lietošanu, depresiju, pretsabiedrisku uzvedību un noziedzību, ar palielinātu nedrošas pārtikas lietošanas risku, plašu somatisko problēmu spektru [10].

Piemēram, lineārās cēlonības saistība ir šāda:

bezdarbnieks $\rightarrow$ nabadzība $\rightarrow$ stress, kas rada konfliktus gimenē $\rightarrow$ vardarbība ǵimenē veicina bērnu vāju socializāciju $\rightarrow$ noziedzīga nodarïjuma izdarī̌sana $[5,17]$. 
Aldona Kipāne. Sociālās vides determinanti un to ietekmes uz dzimumnoziedznieku

kriminologiskais raksturojums

Par gimenes lomu, tās ietekmi un izpētes nozīmīgumu runā gan Rietumu valstu speciālisti, gan Krievijas kriminologi. G̦imenes kriminologija jeb gimenes attiecību kriminologiija varētu būt kriminologiijas nozare, kas pēta giimenes institūta ietekmi uz noziedzīgu uzvedību un noziedzību. Rietumu pasaulē 90. gados sabiedriski politiskās debates par nozieguma dabu un likumpārkāpēja uzvedību koncentrējās uz gimenes lomu. S. Valklate (Walklate) raksta, ka ar ğimenes institūta izmain̄ām arī gimenes nozīmīgums kriminologiskajos pētïjumos ir kḷuvis plašāks [8, 50].

No kriminologijas viedokḷa, par ietekmi uz deviantu uzvedỉbu veicinošiem apstākḷiem var izdalìt četras problēmgrupu gimenes:

1) škirtas gimenes;

2) gimenes, kurās valda nesaskaņas un spriedze;

3) giimenes ar vecāku aprūpes problēmām;

4) gimenes, kurās dzìvo varmāka [11, 50].

G̦imenes kriminologija (krievu val. семейная криминология) Krievijā tiek pētìta kopš pagājušā gadsimta 70. gadiem. Pētnieks D. A. Šestakovs (Шестаков) ìpašu uzmanību pievērš gimenes iekšêjām problēmām un izdala atsevišḳu noziegumu "vardarbība gimenē" [13, 94].

G̦imenes kriminolog̣ijā tiek pētīti šãdi aspekti:

1) noziegumi pret ğimenes locekḷiem (līdz šim visvairāk pētīti vardarbīgi noziegumi pret laulāto un bērnu slepkavības);

2) ǵimenes ietekme uz nepilngadīgo noziedzību;

3) gimenes ietekme uz mantkārīga noziedznieka attīstību;

4) gimenes ietekme uz vardarbīga noziedznieka veidošanos;

5) gimenes ietekme uz noziedzības recidivu;

6) ğimenes iemeslu mehānisms, kas ietekmē noziedzību;

7) noziedzības novēršana, tieši iedarbojoties uz gimenes struktūru.

Turklāt gimenes kriminologija atklāj atgriezenisko saiti starp gimeni un noziedzību, piemēram, kā to ietekmē gimenes attiecības [14, 303], ņemot vērā giimenes kā sociālā institūta nozīmīgumu personas socializācijas gaitā.

Pēc manām domām, ǵimenes kriminolog̣ijai jākḷūst par kriminoloǵijas nozari, kas pēta gimenes institūta ietekmi uz noziedzīgu uzvedỉbu, noziedzību un tās elementiem kopumā.

\section{Secinājums}

1. Seksuāla rakstura noziedzīgos nodarījumus nosaka faktori, kas ir cieši saistīti ar vardarbību, - vara un kontrole pār upuri, kas ir savienota un integrēta ar upura pazemošanu, dominēšanu pār viṇu, cietušā ḷaunprātīgu izmantošanu.

2. Jāṇem vērā g̊imenes kā sociālā institūta nozīmīgums personas socializācijas gaitā. 
Aldona Kipāne. Sociālās vides determinanti un to ietekmes uz dzimumnoziedznieku

kriminologiskais raksturojums

3. Latvijā par kriminoloǵijas apakšnozari jāattīsta "gimenes kriminologiija" jeb "gimenes attiecību kriminolog̣ija", kas pēta ğimenes institūta ietekmi uz noziedzīgu uzvedỉbu un noziedzību. G̦imenes kriminologiija būtu kriminologiijas nozare, kas pēta ğimenes institūta ietekmi uz noziedzīgu uzvedību, noziedzību un tās elementiem kopumā. Viena no ğimenes kriminolog̣ijas izpētes sfērām būtu gimenes ietekme uz vardarbībā iesaistītām personām (vardarbīgā noziedznieka veidošanos un upuri).

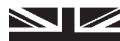 \\ Criminological Characterisation of Environment Factors and Their Impact on Sexual Criminal}

\section{Abstract}

The aim of the article is to reveal the criminological characterisation of environment factors. The article summarises information by several researchers' about environmental factors and their impact on a sexual offender.

Keywords: sexual offender, environment influence, criminological characterisation.

\section{Literatūra un avoti}

\section{Monogrāfijas}

1. Karpova, Ā. G̦imenes psiholoǵija: lekciju kurss. Rīga: RaKa, 2000.

2. Kriminoloǵija: mācību grāmata. Zin. red. Kipēna K., Vilks A. Rīga: Nordik, 2004.

3. Laizāne, I. Jauniešu lìdzatkarības pazìmju saistība ar piesaisti vecākiem, alkohola lietošanu ğimenè un internalizètām un eksternalizètām problēmām: promocijas darbs. Latvijas Universitāte, 2011.

4. Puškarevs, I. Attīstības psiholoǵija. Rīga: Raka, 2001.

5. Einstadter, W. J., Henry, S. Criminological theory: an analysis of its underlying assumptions. USA: Rowman \& Littlefield Publisher, INC, 2006.

6. Malamuth`s model of the characteristcs of coercive men. In: Ward T., Polaschek D., Beech A. R. Theories of sexual offending. Chichester: John Willey \& Sons LtD, 2006.

7. Prinz, R. J. Advances in behavioral assessment of children and families. Vol. 4. Jai Press LTD, 1988.

8. Walklate, S. Understanding criminology: current theoretical debates. New York, Open University Press, 2007.

9. Ward, T., Polaschek, D., Beech, A. R. Theories of sexual offending. Chichester: John Willey \& Sons Ltd., 2006.

10. World report on violence and health. Eds E. G. Krug, Mercy A. J., Zwi B. A. and Lozano R. Geneva: World Health Organization, 2002. 
Aldona Kipāne. Sociālās vides determinanti un to ietekmes uz dzimumnoziedznieku kriminologiskais raksturojums

11. Кризис семьи и преступность. В: Криминология - XX век. ПоА реА. проф. В. Н. Бурлакова, проф. В. П. Сальникова. Санкт-Петербург: ИзАательство "Юридический центр Пресс", 2000.

12. МюстеруА, И., Полесжинский, А. В. Насилие, эволюция и новые факторы окружающей среды. В: Преступность и борьба с ней: новейшие правовые исследования. Сборник научных трудов. Москва: Ининон Ран, 2008.

13. Шестаков, А. А. Семейная криминология: криминофамилистика. Юридический центр, 2003, c. 94.

\section{Interneta resursi}

14. Goodwin, V., Davis, B. Crime families: gender and the intergenerational transfe of criminal tendencies. Iegüts no: http://www.aic.gov.au/publications/current\%20series/tandi/401-420/ tandi414.html [sk. 09.08.2014.].

15. Kjellgren, C. Understanding and managing young sexual offenders: expert report. p. 14. Iegūts no: http://www.childcentre.info/research/perpetrato/acf44b.pdf [sk. 17.10.2014.].

16. Van de Rakt, M., Nieuwbeerta, P. and De Graaf, N. D. Like father, like son. The relationships between conviction trajectories of fathers and their sons and daughters. Iegüts no: http://ics. uda.ub.rug.nl/FILES/root/Articles/2008/RaktMvd-LikeFather/RaktMvd-LikeFather-2008.pdf [sk. 09.08.2014.].

\section{Tiesību akti}

17. Ministru kabineta 2011. gada 5. oktobra rīkojums Nr. 504 "Par sabiedrības veselības pamatnostādnèm 2011.-2017. gadam".

18. Rìcỉbas plāns nepilngadīgo aizsardzỉbai no noziedzīgiem nodarïjumiem pret tikumïbu un dzimumneaizskaramību 2010.-2013. gadam. 